\title{
Вікторія Ліннікова
}

(Чернівці)

\section{ВЕРБАЛЬНІ ЗАСОБИ ВИРАЖЕННЯ СТРАТЕГІЇ «АГРЕСІЯ» В ПОЛІТИЧНИХ ДЕБАТАХ СУЧАСНИХ АМЕКИКАНСЬКИХ ПОЛІТИКІВ}

Розглядаються вербальні засоби вираження агресіі у передвиборчих політичних дебатах 2016 року з урахуванням класифікації К. Ф. Седова. Основними засобами вербалізації агресії виявилися іменники, прикметники, дієслова та займенники. Доведено, щзо Д. Трамп використовує більше вербальних засобів для вираження агресії, ніж його опонент - Г. Клінтон.

Ключові слова: агресія; типи агресії; вербальні засоби вираження агресії; політичні дебати.

Рассматриваются средства выражения вербальной агрессии в предвыборных политических дебатах 2016 года с учетом классификачии К. Ф. Седова. Основныли вербальными средствами выражения агрессии оказались имя существительное, прилагательное, глагол и местоимения. Доказано, что Д. Трамп использует больше вербальных средств для выражения агрессии, чем его оппонент - Х. Клинтон.

Ключевые слова: агрессия; типь агрессии; вербальные средства выражения агрессии; политические дебаты.

The article considers verbal means of aggression expression in political debates between the USA presidential election candidates $D$. Trump and H. Clinton. The research is based on the scripts of three presidential debates in 2016. The topicality of the research is stipulated by the necessity of further elaboration on the notion of verbal aggression as a linguistic phenomenon in the context of political discourse. In accordance with K. F. Sedov classification 5 types of speech aggression have been singled out and regarded in terms of verbal means used to express them. Quantitative analysis has demonstrated that verbal direct 
initiative aggression type reinforced by verbal means prevail in both candidates'speech. D. Trump also resorts to other types: verbal direct mediated, verbal direct emotional, verbal direct active and verbal direct passive aggression. Another essential difference between the two candidates' aggression verbalization is that H. Clinton employs 3 types of verbal means to enhance aggression: pronoun, noun and verb, while her opponent makes use of pronoun, noun, verb and adjective. However, the examples expressing aggression by verbal means in presidential debates are quite immense (180 in D. Trump's speech and 11 in H. Clinton's speech), which suggests that verbal means are often used to convey aggression in political discourse.

Key words: aggression; types of aggression; verbal means of aggression expression; political debate.

«Політичний дискурс - це дискурс на будь-якому політичному форумі, наприклад, кампанії, парламентські дебати, інтерв〉ю, виступи тощо» [13]. «Більша частина досліджень політичного дискурсу стосується тексту та розмов професійних політиків чи політичних інститутів, таких як президент, прем'єр-міністри та інші члени уряду, парламенту чи політичних партій, як на місцевому, національному, так і міжнародному рівнях» [6, с.1152]. Агресія як елемент політичних дебатів потребує подальшого пояснення, а особливо вербальні засоби їі реалізації.

3 психологічної точки зору «агресія» визначається як «насильницькі або ворожі почуття, поведінка чи ставлення» [1]. «Агресія (від лат. «aggressio» - напад, напад) - це вмотивована деструктивна поведінка, що суперечить нормам i правилам співіснування людей у суспільстві, завдаючи шкоди об〉єктам нападу (живим і неживим), завдаючи фізичної шкоди людям (негативний досвід, стани напруги, страху, депресії тощо)» [2].

Дане дослідження спрямоване на лінгвістичний аналіз вербальних засобів вираження агресії. «Вербальна агресія - це використання мовних засобів для вираження неприязні, ворожості, манери мови, що ображають чиюсь самооцінку та гідність» [16, c. 87-104].

Актуальність дослідження обумовлюється відсутністю інформації про вербальні засоби вираження агресії, особливо 
під час політичних дебатів. Матеріалом дослідження є перший, другий та третій передвиборчі політичні дебати між Д. Трампом та Г. Клінтон. Метою дослідження є якісний та кількісний аналіз вербальних засобів вираження агресії у політичних дебатах між двома вище згаданими республіканським та демократичним кандидатами. Для досягнення поставленої мети було використано визначення вербальної агресії та класифікація піi типів запропоновані К. Ф. Седовим. Він розглядає вербальну агресію 3 лінгвістичної точки зору, визначаючи їі як «цілеспрямований комунікативний акт, спрямований на спричинення негативного емоційно-психологічного стану об'єкта мовленнєвого впливу» [16, с.87-104]. Учений виділяє 10 видів мовної агресії: 1. Вербальна / невербальна. 2. Пряма / непряма. 3.Інструментальна / Неінструментальна. 4. Ініціатива / Реактивна. 5. Активна / пасивна. 6. Безпосередня / опосередкована. 7. Спонтанна / підготовлена. 8. Емоційна / раціональна.9. Сильна / слабка. 10. Ворожа / неприязна. Ми згрупували їх у більш складні типи, представлені наступними абревіатурами: ВПА (вербальна пряма активна); ВПП (вербальна пряма пасивна); ВПІ (вербальна пряма ініціатива); ВПР (вербальна пряма реактивна); ВПО (вербальна пряма опосередкована); BEA (вербальна емоційна активна); BIA (вербальна ініціативна активна); ВДЕ (вербальна пряма емоційна). Їх приклади в контексті першого, другого та третього політичних дебатів Д. Трампа та Г. Клінтон будуть проаналізовані в даній статті.

3 метою звуження пошуку звертали увагу на використання займенників та лексики, які можуть виражати агресивне ставлення до опонента. Референти займенників, а також значення, вкладене ораторами, показані в прикладах нижче.

У першому політичному дебаті агресія представлена такими негативними іменниками: бійка (a fight), катастрофа (a disaster), ганьба (a shame), проблема (a problem), темперамент (a temperament); прикметниками: ганебний (disgraceful), дефективний (defective) та фразами бути звинуваченим за щось (to be blamed for), розтрачувати на (squandered on).

У другому політичному дебаті переважають дієслова: нападати (to attack), брехати (to lie), боротися (to fight) і бути присоромленим за (to be ashamed of). Агресія виражається іменниками такими, як: 
повістка (a subpoena,), брехня (a lie). Прикметник: образливий (abusive).

Третій дебат містить такі слова, що виражають агресію: прикметники: сердитий (angry), винен (guilty) і сфальсифікований (rigged); Іменники: насильство (violence), злочин (a crime). Усі ці слова можна розділити на групи за своїм значенням.

Таблиця 1.1

Агресивна лексика, що використовується в дебатах

\begin{tabular}{|c|c|c|}
\hline Дебат & $\begin{array}{l}\text { Нейтральна лексика, } \\
\text { що стала негативною }\end{array}$ & Негативна лексика \\
\hline I & Темперамент & $\begin{array}{c}\text { Незаконний } \\
\text { Ганебний } \\
\text { Дефективний } \\
\text { Бути звинуваченим у чомусь } \\
\text { Ганьба } \\
\text { Проблема } \\
\text { Бійка } \\
\text { Катастрофа }\end{array}$ \\
\hline II & Повістка & $\begin{array}{c}\text { Ганебний } \\
\text { Катастрофа } \\
\text { Брехня } \\
\text { Брехати } \\
\text { Атакувати } \\
\text { Боротися } \\
\text { Бути присоромленим за } \\
\text { Образливий } \\
\end{array}$ \\
\hline III & - & $\begin{array}{c}\text { Злочин } \\
\text { Розлючений } \\
\text { Винний } \\
\text { Злий } \\
\text { Підроблений } \\
\text { Насильство } \\
\text { Нечесний }\end{array}$ \\
\hline $\begin{array}{l}\text { Загальна } \\
\text { кількість }\end{array}$ & 2 & 22 \\
\hline
\end{tabular}


У таблиці 1.1 представлено використання негативної лексики в окремих дебатах. Представлено також зміни значення слів 3 нейтральних на негативні, тому можна припустити, що лексика, яка використовується в політичних дебатах між Д. Трампом та Г. Клінтон $є$ переважно негативною. Результати таблиці 1.1 демонструють, що обидва кандидати використовують 22 слова 3 негативним значеням в той час, як лише 2 слова змінили своє значення на негативне.

Проаналізуємо використання негативного лексису стосовно типу агресії.

ВПО: "TRUMP: Our jobs are fleeing the country. They>re going to Mexico. Theysre going to many other countries. You look at what China is doing to our country in terms of making our product. They re devaluing their currency, and theress nobody in our government to fight them. And we have a very good fight. And we have a winning fight. Because they're using our country as a piggy bank to rebuild China, and many other countries are doing the same thing" [4].

Ми хочемо підкреслити, що «В» в абревіатурі означає вербальна. «П» означає пряма, і це означає, що Д. Трамп не намагається прикрити своє негативне ставлення до нинішньої влади, але він чітко висловлює своє незадоволення їх діями. Він протиставляє себе та свою партію нинішній владі, пояснюючи, що їхні дії ефективні та варті уваги виборців. «О» означає опосередкована, оскільки Д. Трамп посилається на минуле, і він не чітко викладає факти, на яких грунтуються його припущення. Слово «боротьба/ боротися» (“fight") представлено тут як іменник і дієслово. Ще більш важливо те, що дієслово поєднується з заперечним та особовими займенниками. "Nobody" використовується для звернення до уряду, щоб зробити його неефективними без зазначення конкретних людей. Д. Трамп використовує дієслово «боротися» (“fight”) у поєднанні 3 заперечним займенником, значення якого полягає «спробі запобігти успіху чи ефективності» [9], тоді як іменник «бійка» (“fight”) вживається в контексті 3 особовим займенником «ше» для вираження підмета. Значення іменника - «ситуація, в якій ви докладаєте багато зусиль, щоб перемогти когось або чогось домогтися, або для того, щоб щось не відбулося» [9]. “Wе” використовується для виділення хороших 
якостей оратора та його команди, підкреслюючи значення слова «боротися» епітетами, "good" and "winning".

ВПЕ: "Trump: Let me give you the example of Mexico. They have a VAT tax. Werre on a different system. When we sell into Mexico, there>s a tax. When they sell in -- automatic, 16 percent, approximately. When they sell into us, there s no tax. It's a defective agreement. It's been defective for a long time, many years, but the politicians haven't done anything about it.

Now, in all fairness to Secretary Clinton -- yes, is that OK? Good. I want you to be very happy. It's very important to me.

But in all fairness to Secretary Clinton, when she started talking about this, it was really very recently. She's been doing this for 30 years. And why hasn't she made the agreements better? The NAFTA agreement is defective. Just because of the tax and many other reasons, but just because of the fact..." [4].

Розглянемо детальніше абревіатуру в цьому прикладі. Оскільки букви «В» та «П» вже були пояснені, ми хочемо звернути вашу увагу на букву «Е». Це означає емоційну агресію, яка спрямована на афективний вплив на слухача. Дональд наголошує, що секретар Клінтон неефективна як політик, але він намагається приховати свої реальні наміри фразою «I want you to be very happy. It's very important to me», використовуючи цю фразу, він намагається створити певний позитивний образ для себе. Політик, який піклується про всіх, навіть свого опонента. Використання прикметника «дефективний» (“defective”), значення якого - «щось, у чому є несправність і не працює належним чином» [5], дозволяє йому продовжувати свою промову і перейти до звинувачень проти Клінтон. Тут ми бачимо вживання особового займенника «вона». За допомогою цього займенника Дональд відділяє Гілларі від інших політиків і робить іiі відповідальною за неефективність угоди. Дональд звинувачує іï в тому, що за тридцять років політичної кар>єри вона іiї не покращила. Він також робить припущення, що нічого не зміниться, оскільки вона почала говорити про це зовсім недавно.

ВПI: "TRUMP: You are going to approve one of the biggest tax cuts in history. You are going to approve one of the biggest tax increases in history. You are going to drive business out. Your regulations are a 
disaster, and you're going to increase regulations all over the place" [4].

Буква «I» означає ініціативну агресію, що означає, що Дональд Трамп активно висловлює недовіру політичним поглядам Г. Клінтон і хоче, щоб вона захищала себе від його звинувачень. Економічна стратегія, на яку зазвичай посилається Г. Клінтон, критикується іiі опонентом. Він назвав їі економічний план «катастрофою» (“disaster”), значення цього слова - «дуже невдалий або вкрай поганий» [7]. Трамп натякає, що вона не зможе виконати передвиборні обіцянки, оскільки всі вони призведуть до жахливих наслідків. Що ще важливіше, він використовує фрази, "to drive business out" and "to increase regulations", підкреслюючи, що таке регулювання знищить приватний бізнес та встановить державну монополію.

ВПА: "ТRUМР: That was more than a mistake. That was done purposely. OK? That was not a mistake. That was done purposely. When you have your staff taking the Fifth Amendment, taking the Fifth so they're not prosecuted, when you have the man that set up the illegal server taking the Fifth, I think it's disgraceful. And believe me, this country thinks it's -- really thinks it's disgraceful, also" [4].

Буква «А» в абревіатурі ВПА ще не пояснена, тому необхідне подальше пояснення. «А» означає активну агресію за якої оратор відкрито висловлює своє негативне ставлення до конкретної людини чи ситуації. Одним із способів переконати виборців, якими користуються політики, є перевірка фактів на їхніх сайтах. Д. Трамп звинувачує Г. Клінтон у неправдивості поданої інформації. Для того, щоб посилити зневагу до ії вчинку, він скористався словом «ганебний» (“disgraceful”), що означає «притягнення ганьби» [8]. Дональд експлуатує антонімічні речення “That was not a mistake. That was done purposely”, вказуючи на те, що Гілларі намагалася приховати політичні дані. Він намагається зробити себе частиною країни і використовує метонімію “country thinks”. Він намагається переконати виборців у правдивості його слів.

ВПП: "ТRUMP: Well, I have much better judgment than she does. There's no question about that. I also have a much better temperament than she has, you know?" [5].

Буква «П» позначає пасивну агресію. Даний тип агресії 
передбачає ігнорування оратором осуду опонентів. У наведеному вище прикладі ми бачимо, що республіканський висуванець не відповідає на попереднє звинувачення, а навпаки, він хвалить себе і принижує свого опонента. Перевага особистого займенника «я» полягає в тому, що він демонструє здатність Дональда приймати рішення. Недоліком може бути те, що він занадто чітко показує, де криється провина, він проводить лінію між собою та Гілларі. Для подальшого покращення своєї точки зору Дональд використовує прикметники у найвищому ступені порівняння та іменники, що вказують, що він перебуває у кращому становищі, ніж Гілларі. Слово «темперамент» (“temperament”) тут вживається в прямому значенні «своєрідний або відмітний психічний або фізичний характер» [14], однак, використовуючи свою антифеміністичну позицію, Дональд ставить себе над Гілларі, натякаючи, що вона не може приймати правильних рішень.

ВПІн.: "Trump: And I will tell you that when Hillary brings up a point like that and she talks about words that I said 11 years ago, I think it's disgraceful, and I think she should be ashamed of herself, if you want to know the truth" [12].

«Ін» - інструментальна агресія, яка передбачає агресію на подразник. Використовуючи слово «ганебний» (“disgraceful”) стосовно Гілларі, Дональд намагається відвернути увагу глядачів від себе і вказати, що Гілларі спотворює факти. Поєднання особових та зворотніх займенників відрізняють Гілларі від Дональда. Він чітко розмежовує їх обох, щоб вживати фразу «має бути соромно за» (“to be ashamed of”), що означає «почувати себе винним чи збентеженим з приводу того, що ви зробили для більш драматичного ефекту» [3].

ВПІ: "CLINTON: Well, Chris, let me respond to that, because that's horrifying. You know, every time Donald thinks things are not going in his direction, he claims whatever it is, is rigged against him.

The FBI conducted a year-long investigation into my e-mails. They concluded there was no case; he said the FBI was rigged. He lost the Iowa caucus. He lost the Wisconsin primary. He said the Republican primary was rigged against him. Then Trump University gets sued for fraud and racketeering; he claims the court system and the federal judge is rigged against him. There was even a time when he didn't 
get an Emmy for his TV program three years in a row and he started tweeting that the Emmys were rigged against him" [15].

Гілларі використовує слово «жахливий» ("horrifying"), що означає «дуже шокуюче» [10], відповідаючи на звинувачення Д. Трампа. Д. Трамп бомбардує Г. Клінтон звинуваченнями в наступній нечесній кампанії. Вона навмисно вживає слово «сфальсифікований» (“rigged”), що означає «нечесно влаштовуваний результат чогось, наприклад, виборів» [11]. Вона використовує іронічні висловлювання, щоб показати, що всі місця та події, які Трамп назвав «сфальсифікованими» (“rigged”) проти нього, не є реальними і існують лише в його свідомості. Таким чином, вона намагається зберегти свій образ чесного політичного діяча і переконати виборців, що Трамп намагається ними маніпулювати. Клінтон навмисно опускає займенник «я» $\mathrm{i}$ вимовляє весь уривок із займенником «він». Вона відокремлює себе від таких дій і пояснює, що завжди погоджується з результатами, але він вважає їх сфальсифікованими.

BEA: "CLINTON: I have a feeling that by, the end of this evening, I'm going to be blamed for everything that's ever happened.

TRUMP: Why not?

CLINTON: Why not? Yeah, why not?" [4].

BEA позначає вербальну емоційну активну агресію. Активна агресія спрямована на відображення незгоди зі словами опонента, а емоційна має на меті схилити виборців підтримати сторону Гілларі Клінтон. Гілларі бере на себе роль політичного діяча, який чітко виконує свою роботу. На відміну від неї, є людина, яка звинувачує їі у всіх політичних невдачах країни. Вона використовує фразу «бути звинуваченим в чомусь» (“to be blamed for"), як підтвердження того, всі звинувачення Дональда є безпідставними і продемонструвати, що вона є причиною не тільки поганих рішень у країні, але й хороших.

Як зазначалось раніше, кожен приклад у цій частині класифікується абревіатурою, яка вказує на конкретні типи агресії, які використовуються кандидатами. У таблиці 1.2 представлений кількісний аналіз цих типів. 
Таблиця 1.2

Види агресії у виборчих дебатах, виражених за допомогою вербальних засобів

\begin{tabular}{|c|c|c|c|}
\hline \multicolumn{2}{|c|}{ Д. Трамп } & \multicolumn{2}{c|}{ Г. Клінтон } \\
\hline ВПО & 5 & ВЕА & 1 \\
\hline ВПЕ & 1 & ВПІ & 1 \\
\hline ВПІ & 8 & & \\
\hline ВПА & 2 & & \\
\hline ВПП & 1 & & 2 \\
\hline Разом & 17 & & \\
\hline
\end{tabular}

Таблиця 1.2 демонструє те, що Д. Трамп використовує п’ять типів вербальної агресії, і переважаючим для нього є пряма вербальна ініціативна. Г. Клінтон значно рідше висловлює своє негативне ставлення до Д. Трампа за допомогою вербальних засобів та передусім шляхом вербальної прямої ініціативної та вербально емоційно-активної видів агресії.

Дані таблиці 1.3 показують, що Д. Трамп використовує 7 типів займенників для вираження агресії. Особові займенники переважають у промові республіканського кандидата. Об〉єктні займенники та присвійні прикметники також зустрічаються в його промовах, проте є не такими частими як особові займенники. Присвійні займенники, зворотні займенники, вказівні займенники та заперечні займенники рідко використовуються Д. Трампом під час політичних дебатів.

Таблиця 1.3

Займенники, використовувані Д. Трампом в агресивному контексті у виборчих дебатах

\begin{tabular}{|c|c|c|c|c|c|c|c|c|c|c|c|c|c|}
\hline $\begin{array}{l}\overrightarrow{0} \\
\overline{0} \\
8 \\
8 \\
0\end{array}$ & 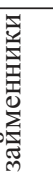 & $\begin{array}{l}\bar{I} \\
\bar{E} \\
0 \\
8\end{array}$ & 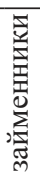 & 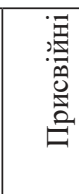 & & 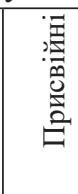 & & $\begin{array}{ll} & \bar{z} \\
0 \\
0 \\
0 \\
0\end{array}$ & & 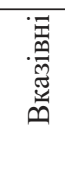 & & 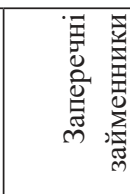 & \\
\hline I & 15 & $\mathrm{Me}$ & 4 & My & 1 & Mine & 1 & Her-self & & This & 2 & Nobody & 1 \\
\hline You & 24 & Her & 1 & Your & 3 & & & & & That & 5 & Anybody & 1 \\
\hline $\mathrm{He}$ & 9 & Us & 2 & His & 2 & & & & & Those & 1 & Everybody & 1 \\
\hline She & 18 & Them & 5 & Her & 1 & & & & & & & & \\
\hline
\end{tabular}




\begin{tabular}{|c|l|l|l|l|l|l|l|l|l|l|l|l|l|}
\hline It & 24 & & & Our & 9 & & & & & & & & \\
\hline We & 11 & & & Their & 1 & & & & & & & & \\
\hline They & 14 & & & & & & & & & & & & \\
\hline Разом & 115 & & 12 & & 17 & & 1 & & 1 & & 8 & & 3 \\
\hline
\end{tabular}

Таблиця 1.4 демонструє, що Г. Клінтон використовує 4 типи займенників для вербалізації агресії. У порівнянні з ії опонентом вона використовує менше типів займенників, проте переважаючими $\epsilon$ особові займенники для обох кандидатів. Об〉єктні займенники, присвійні прикметники та вказівні займенники рідко зустрічаються в іiï промовах.

Таблиця 1.4

Займенники, які використала Г. Клінтон в агрессивному контексті у виборчих дебатах

\begin{tabular}{|l|l|l|l|l|l|l|l|}
\hline $\begin{array}{l}\text { Особові } \\
\text { займенники }\end{array}$ & $\begin{array}{l}\text { Об'єктні } \\
\text { займенники }\end{array}$ & \multicolumn{2}{l|}{$\begin{array}{l}\text { Присвійні } \\
\text { прикметники }\end{array}$} & $\begin{array}{l}\text { Вказівні } \\
\text { займенники }\end{array}$ \\
\hline I & 2 & Me & 1 & My & 1 & That & 1 \\
\hline He & 8 & Him & 4 & His & 1 & & \\
\hline It & 1 & & & & & & \\
\hline They & 1 & & & & & & \\
\hline Paзом & 12 & & 5 & & 2 & & 1 \\
\hline \multicolumn{7}{|l|}{ Paзом: 20}
\end{tabular}

Дані таблиця 1.4 демонструють, які типи займенників вживає демократичний кандидат.

У результаті аналізу було встановлено, що обидва кандидати використовують різну кількість вербальних засобів для вираження агресії. Д. Трамп використовує 180 вербальних засобів; тим часом Г. Клінтон використовує 25 засобів. Результати кількісних аналізів показують, що займенники переважають у Д. Трампа. Вони трапляються 158 разів і складають 88\% вербальних засобів. Прикметники вживаються 7 разів (4\%), а іменники вживаються 11 разів (5\%). Рідше - дієслова; їх вживають лише 4 рази (3\%). Займенники є домінуючими у Г. Клінтон. Їх вона застосовує 20 разів (80\%). Вона послуговується прикметниками 3 рази (12\%) та дієсловами двічі (8\%) для вираження агресії. Поряд з вербальними засобами для вираження агресії кандидати використовують різні типи агресії за класифікацією К. Ф. Седова. Д. Трамп застосовує 
вербальні засоби для вираження агресії ВПО (25\%), ВПЕ (6\%), ВПІ (50\%), ВПА (13\%), ВПП (6\%) агресії. Г. Клінтон використовує вербальні засоби для агресії ВЕА (50\%) та ВПІ (50\%).

Практичне значення зумовлюється перспективою використання результатів дослідження в аналізі вербальних засобів вираження агресії у політичних дебатах інших політиків або в інших типах дискурсу.

\section{Список літератури}

1. Aggression. Cambridge Dictionary: веб-сайт. URL: https:// dictionary.cambridge.org/ru/ $\% \mathrm{D} 1 \% 81 \% \mathrm{D} 0 \% \mathrm{BB} \% \mathrm{D} 0 \% \mathrm{BE} \% \mathrm{D} 0 \%$ B2\%D0\%B0\%D1\%80\%D1\%8C/\%D0\%B0\%D0\%BD\%D0\%B3 $\%$ D0\%BB $\%$ D0\%B8\%D0\%B9\%D1\%81\%D0\%BA\%D0\%B8\%D0 $\% \mathrm{~B} 9 /$ aggression

2. Aggression. Oxford Dictionary: веб-сайт. URL: https://www.lexico. com/en/definition/aggression

3. Ashamed. Cambridge Dictionary: веб-сайт. URL: https://dictionary. cambridge.org/ru/ashamed

4. Blake A. The first Trump-Clinton presidential debate transcript, annotated: веб-сайт: URL: https://www.washingtonpost.com/news/ the-fix/wp/2016/09/26/the-first-trump-clinton-presidential-debatetranscript-annotated/

5. Defective. Cambridge Dictionary: веб-сайт. URL: https://dictionary. cambridge.org/dictionary/english/defective

6. Denton R., Hahn D. Presidential Communication. New York: Praeger, 1986. p.17-41

7. Disaster. Cambridge Dictionary: веб-сайт. URL: https://dictionary. cambridge.org/dictionary/english/disaster

8. Disgraceful. Merriam-Webster Dictionary: веб-сайт. URL: https:// www.merriam-webster.com/dictionary/disgraceful

9. Fight. Cambridge Dictionary: веб-сайт. URL: https://dictionary. cambridge.org/dictionary/english/fight

10.Horrifying. Cambridge Dictionary: веб-сайт. URL: https:// dictionary.cambridge.org/dictionary/english/horrifying

11. Rigged. Cambridge Dictionary: веб-сайт. URL: https://dictionary. cambridge.org/ig?q=rigged

12.Second 2016 presidential debate: Full transcript. Politico Staff: 
веб-сайт. URL: https://www.politico.com/story/2016/10/2016presidential-debate-transcript-229519

13. Sharndama E. C. Discursive strategies in political speech: a critical discourse analysis of selected inaugural speeches of the Nigeria's gubernatorial inaugurals. European Journal of English Language, Linguistics and Literature.2016. Vol. 3. No. 2, 2015. URL: https:// www.idpublications.org/wp-content/uploads/2016/06/Full-PaperDISCURSIVE-STRATEGIES-IN-POLITICAL-SPEECH-ACRITICAL-DISCOURSE-ANALYSIS.pdf

14. Temperament. Merriam-Webster Dictionary: веб-сайт. URL: https://www.merriam-webster.com/dictionary/temperament

15.Third Presidential Debate Between Donald Trump and Hillary Clinton:Full Transcript. Fortune Staff: веб-сайт. URL: https:// fortune.com/2016/10/19/presidential-debate-third-transcript/

16.Седов К.Ф. Агрессия и манипуляция в повседневной коммуникации. Челябинск. 2005. 87-104 с.

\section{References Transliterated}

1. Sedov K.F. Agressiya i manipulyaciya $v$ povsednevnoj kommunikacii. CHelyabinsk. 2005. 87-104 s. 